
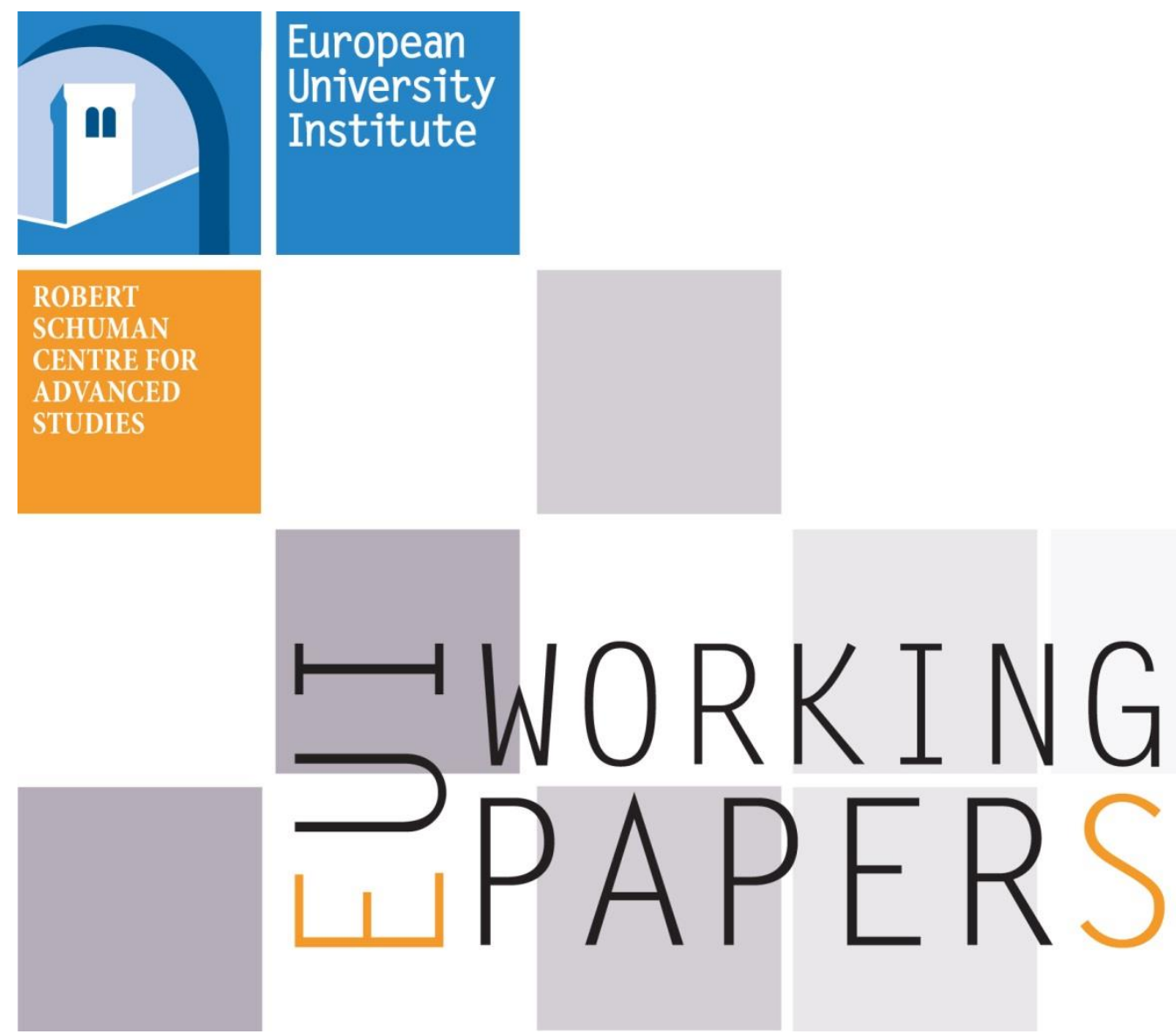

\title{
RSCAS 2014/85
}

Robert Schuman Centre for Advanced Studies Florence School of Regulation

Enhancing flexibility and ensuring efficiency and security: Improving the electricity market in Brazil via a virtual reservoir model

Felipe A. Calabria, J. Tomé Saraiva and Jean-Michel Glachant 

European University Institute

Robert Schuman Centre for Advanced Studies

Florence School of Regulation

Enhancing flexibility and ensuring efficiency and security:

Improving the electricity market in Brazil via a virtual reservoir model

Felipe A. Calabria, J. Tomé Saraiva and Jean-Michel Glachant

EUI Working Paper RSCAS 2014/85 
This text may be downloaded only for personal research purposes. Additional reproduction for other purposes, whether in hard copies or electronically, requires the consent of the author(s), editor(s). If cited or quoted, reference should be made to the full name of the author(s), editor(s), the title, the working paper, or other series, the year and the publisher.

ISSN 1028-3625

(C) Felipe A. Calabria, J. Tomé Saraiva and Jean-Michel Glachant, 2014

Printed in Italy, September 2014

European University Institute

Badia Fiesolana

I - 50014 San Domenico di Fiesole (FI)

Italy

www.eui.eu/RSCAS/Publications/

www.eui.eu

cadmus.eui.eu 


\section{Robert Schuman Centre for Advanced Studies}

The Robert Schuman Centre for Advanced Studies (RSCAS), created in 1992 and directed by Brigid Laffan since September 2013, aims to develop inter-disciplinary and comparative research and to promote work on the major issues facing the process of integration and European society.

The Centre is home to a large post-doctoral programme and hosts major research programmes and projects, and a range of working groups and ad hoc initiatives. The research agenda is organised around a set of core themes and is continuously evolving, reflecting the changing agenda of European integration and the expanding membership of the European Union.

Details of the research of the Centre can be found on:

http://www.eui.eu/RSCAS/Research/

Research publications take the form of Working Papers, Policy Papers, Distinguished Lectures and books. Most of these are also available on the RSCAS website:

http://www.eui.eu/RSCAS/Publications/

The EUI and the RSCAS are not responsible for the opinion expressed by the author(s).

\section{Florence School of Regulation}

The Florence School of Regulation (FSR) is a partnership between the Robert Schuman Centre for Advanced Studies (RSCAS) at the European University Institute (EUI), the Council of the European Energy Regulators (CEER) and the Independent Regulators Group (IRG). Moreover, as part of the EUI, the FSR works closely with the European Commission.

The objectives of the FSR are to promote informed discussions on key policy issues, through workshops and seminars, to provide state-of-the-art training for practitioners (from European Commission, National Regulators and private companies), to produce analytical and empirical researches about regulated sectors, to network, and to exchange documents and ideas.

At present, its scope is focused on the regulation of Energy (electricity and gas markets), of Communications \& Media, and of Transport.

This series of working papers aims at disseminating the work of scholars and practitioners on current regulatory issues.

For further information

Florence School of Regulation

Robert Schuman Centre for Advanced Studies

European University Institute

Via Boccaccio, 151

I-50133 Firenze

Tel.: +39055 4685751

Fax: +39055 4685755

E-mail: fsr@eui.eu

http://www.eui.eu/RSCAS/ProfessionalDevelopment/FSR/ 



\begin{abstract}
The Brazilian electricity market has certain particularities that contribute to considerably distinguish it from other markets. With a continental interconnected transmission system in which around $70 \%$ of the total installed capacity comes from hydropower plants, this electricity market recently passed through two large institutional reforms and it currently contains a number of special features together with other usual market instruments. Nevertheless, the conciliation between the commercial commitments of the market participants and the physical dispatch is not smooth. Moreover, the Brazilian short-term market is a mechanism to settle differences rather than a market, and the electricity short-term market price and the schedule dispatch are not determined through the interaction between market participants. This paper focuses on these problems, discusses some dilemmas that have to be faced if a more conventional market oriented approach is to be adopted, and proposes a solution in order to address these issues. Pointing towards the enhancing of the flexibility for market participants to bear their contracts, while still ensuring the efficient use of the energy resources and maintaining the current level of the security of supply, this new framework was designed based on a virtual reservoir model.
\end{abstract}

\title{
Keywords
}

Brazilian electricity market, market design, virtual reservoir model 



\section{Introduction}

The electricity industry has changed over the years from vertically integrated utilities to more decentralized structures and competitive electricity markets. Ever since, several electricity market structures are being designed and tested to ensure free access, fair competition, higher efficiency, while maintain or improving reliability and security of operation.

The Brazilian electricity market has certain particularities that contribute to considerably distinguish it from other markets. With a continental interconnected transmission system, a large and growing demand, a total generation installed capacity around $135 \mathrm{GW}$, from which around $70 \%$ comes from hydropower plants, this electricity market passed through two large institutional and regulatory reforms in the last 20 years and it currently contains special instruments such as the Mechanism for Reallocation of Energy and the Seasonalization process.

The first reform promoted a transition from the vertical integrated utility structure to a market where agents could freely negotiate contracts. Besides that, the quantities that were traded by contracts have been reduced whereas more trading in the short-term market was encouraged (Arango et. al., 2006). During this time, Brazil had a decentralized energy planning, but with an indicative energy planning conducted by the National Council for Energy Policy (CNPE). Then, in 2001 Brazil experienced a major supply crisis, which led to an aggressive energy rationing from June 2001 to February 2002. The 2001/2002 energy rationing had major economic and political impacts and encompassed about $80 \%$ of population, GDP and electricity consumption (Maurer et. al., 2005).

Driven by the mentioned rationing, the second reform took place as an electoral commitment of the opposition party, who won the Presidential election in 2002. This reform basically pushed Brazil to a structure corresponding to the single buyer model, but preserving some competition features in the retail market. In practice, a new regulatory framework (introduced by Law 10848/2004) was implemented in 2004 bringing back some old fundaments and adding new guidelines:

A. Reintroduction of the long-term centralized planning conducted by the federal government to address the security of supply. Thus, the expansion of the system doesn't rely on a market-based economy;

B. Competition through public auctions according to the single buyer model. The main target of this scheme is to provide affordable tariffs to the growing economy;

C. Implementation of long-term contracts (PPAs) with availability of payment. The goal was to foster the installation of thermal power plants;

D. Requirement that consumers must be fully supplied by energy and power purchase contracts, and all contracts must be registered in the Brazilian market operator (CCEE);

E. Requirement that sellers must have enough capacity when selling energy and power to entirely ensure their contracts; and

F. Restructuring of the commercialization processes by creation of two contracting environments: the ACR Regulated Contracting Environment and the $A C L$ - Free Contracting Environment.

Both the implementation of PPAs with availability of payment (item C) and a mandatory bilateral contracting scheme (item D) with physical backing (item E) were adopted to guarantee the return of investments and address the security of supply, since this was appointed as one of the reasons of the above mentioned rationing.

Regarding item D, it is relevant to reinforce that the electricity demand of both distribution utilities (on behalf of captive consumers) and free consumers must ensure the compliance of $100 \%$ of their consumptions by energy and power purchase bilateral contracts (Decree 5163/2004, art $2^{\circ}$, items II and III). Otherwise, specified penalties will be applied to them. As a result, this legal provision definitely imposes a bottleneck on the trading of electricity into the short-term market. 
Concerning item E, it means that all electricity sold by sellers should be $100 \%$ physically backed (Decree 5163/2004, art $2^{\circ}$, item I). This "physical coverage for sale" consists of what is known as "physical guarantee" of the power plants. The physical guarantee corresponds to the maximum amounts of energy associated with each power plant project. Relating to hydros, physical guarantee corresponds to the maximum energy production that can be maintained almost continuously over the years, simulating the occurrence of thousands of inflow sequences created statistically, and assuming a certain risk of not feeding the load (ANEEL, 2013). To sum up, the physical guarantee, which is defined by the Ministry of Mines and Energy (MME), has the value of a certificate that determines the amount of energy that each power plant can trade.

\section{From Market Results to Physical Operation of the Power System}

For end consumers, the Brazilian electricity market operates in two ways. It operates under competition in the retail market, named $A C L$, for those eligible consumers that fit in the characteristic of free consumers or special consumers, and it works according to the single buyer model structure, entitled $A C R$, for the final consumers that are not free to choose their supplier.

In the $A C R$, prices are determined by national public auctions. Differently, in the $A C L$ prices are freely negotiated between buyers and sellers through a non-organized market like OTC, where a lot of traders can mediate the deal between consumers and producers, or through emerging private power exchanges. Additionally, there is also the short-term market, in Brazil known as $M C P$, which is designed to account for and settle the differences between the contracted energy amounts and the generated/consumed energy.

There are several kinds of national public auctions. Some of them are implemented to buy "new energy", i.e. electricity that will be produced by power plants that still have to be built, while others aim at buying electricity from power plants already under operation. Moreover, there are also specific auctions designed to buy electricity only from renewable energy sources (such as wind, PV, biomass and small hydros), to raise the level of security of supply (reserve energy auction), and to promote the feasibility of relevant and structuring projects. Figure 1 shows average prices of $A C R$ auctions carried out between 2004 and 2012 by energy source.

Figure 1 - Average prices by types of auctions in Brazil (Rosa et. al., 2013)

Price of contracts (US\$ - July 2012)

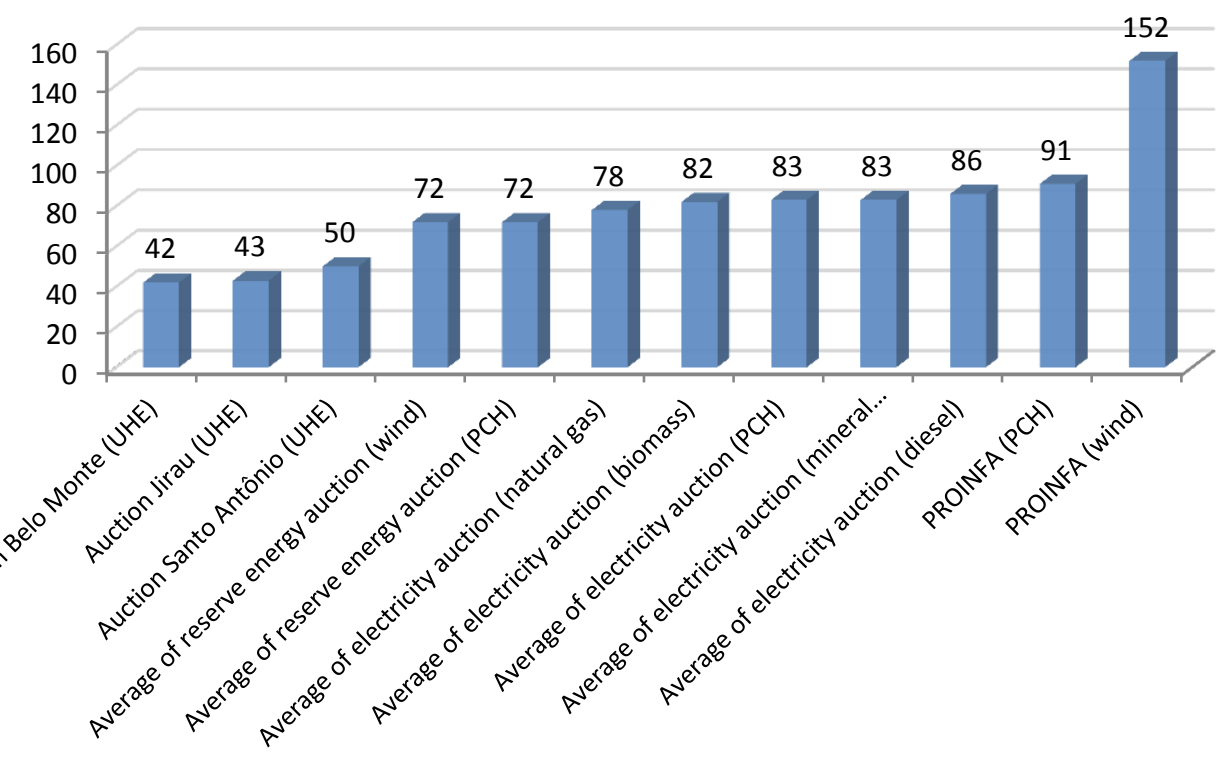


Then, all contracts must be registered at the market operator (CCEE) in order to be considered in the settlement process of the $M C P$. Additionally, when a power plant becomes available for operation, the CCEE considers the associated physical guarantee available to be also settled. Then, regularly in December of every year, market participants can perform a seasonal adjustment of the contracted energy and of the physical guarantee to be applied for the entire next year (CCEE, 2012). This process is called "seasonalization" and, in other words, it allows distributing the total annual amount in monthly MWh packages. Besides the seasonalization, the MWh are also allocated in three load steps, in a process known as "modulation".

The power plants are then dispatched by the system operator (ONS) in order to optimize the hydrothermal system and to efficiently use energy resources. The dispatch is performed without considering the amount of the contracted energy and physical guarantee. Instead of a market-based approach, the dispatch is defined based on the solution of a minimum operational cost problem that seeks for a trade-off between saving water now and using thermal fuel (if the expectation of inflows is low) or using water now and saving thermal fuel (if the expectation of inflows is favourable). Furthermore, concerning the coordination of the operation, since there are a lot of cascades of hydro stations with different owners, it is also important to consider the use of the potential energy stored in the reservoirs installed in the same water basin.

As a consequence, the dispatch is centralized and the optimal dispatch problem is currently solved basically through a stochastic dynamic programming software package called NEWAVE together with a linear programming software called DECOMP. The two main outputs of these two packages are as follows: the dispatch schedule of the power plants under operation and connected to the National Interconnected System; and the Brazilian short-term market prices, well-known as PLD (Price of the Differences Settlement). Both of them are weekly established for each load step of the day.

Because the dispatch is performed by the ISO in a centralized way and it decides the market participants' outputs without considering their contracted energy, and once generators need to bear their contracts by delivering the electricity committed through contracts, there is in Brazil a mechanism called Mechanism for Reallocation of Energy (MRE). The MRE is applied to hydros, that usually close contracts following the modality for quantity, i.e., they are committed to deliver a certain amount of electricity (MWh) during a specific period at a pre-defined price. The goal of this mechanism is to cover the risk of generators having to buy electricity in the short-term market at PLD to fill in the amount of energy committed in their contracts.

All generators receive their contractual payment because they sell the "physical guarantee assigned to them", and not because they sell the "actual electricity produced by them". Then, in each accounting period, the $M R E$ reallocates energy, transferring the surplus generated from those that produce beyond their physical guarantee to those that produce below. So, if the own production of a hydro station is less than its physical guarantee (which is calculated in long term to represent the amount of electricity that can be continuously produced), this station will receive energy from stations that produced more.

The own production plus the energy allocated from the $M R E$ is equal to the verified energy, which is then compared with the contracted energy, and the resulting difference is settled in the short-term market $(M C P)$ at the short-term market price $(P L D)$. This settlement is performed for each agent and it is illustrated in Figure 2. 


\section{Figure 2 - Traded energy in MCP: negative exposition}

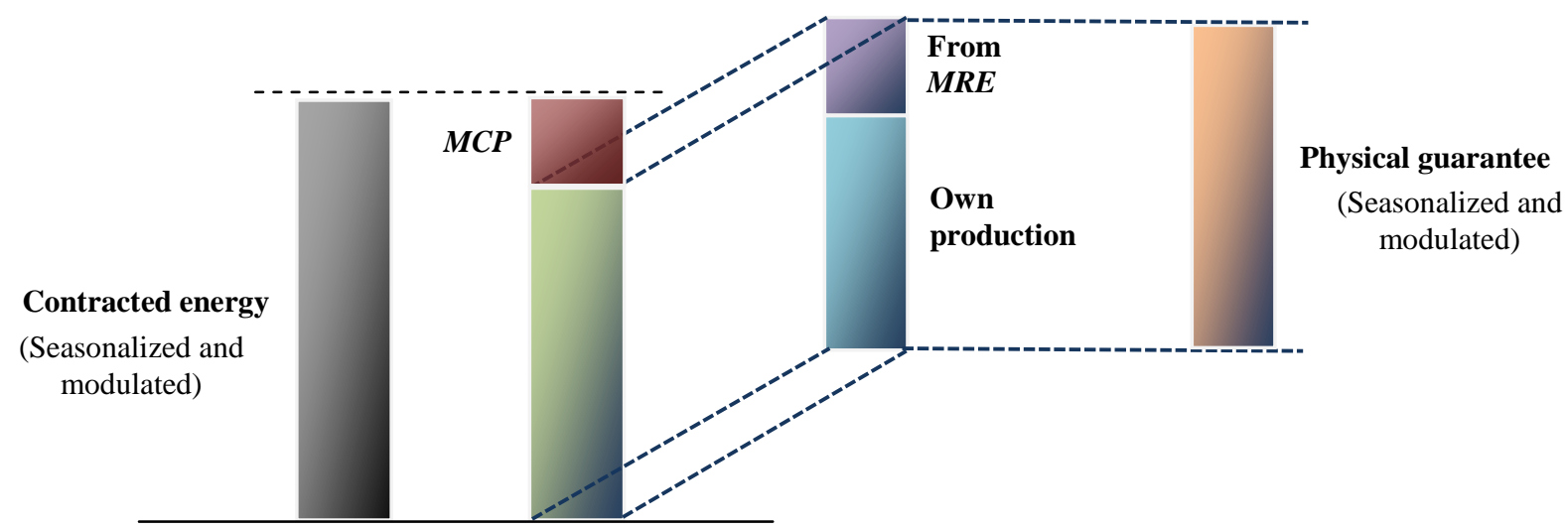

To bring this section to a close, Table 1 shows a number of types of contracts from both the ACR and the $A C L$, and briefly explains how the dispatch procedure is carry out by the system operator (ONS) and the settlement of exposed positions performed by the market operator (CCEE).

Table 1 - The ACR and ACL markets, the dispatch procedure and the MCP

\begin{tabular}{|c|c|c|c|}
\hline $\begin{array}{ll}A C R \quad-\quad \text { Regulated } \\
\text { Contracting } & \\
\text { Environment } & \\
\end{array}$ & $\begin{array}{l}A C L \quad- \\
\text { Contracting } \\
\text { Environment } \\
\end{array}$ & $\begin{array}{l}\text { ISO dispatch } \\
\text { procedure }\end{array}$ & $\begin{array}{l}\text { Brazilian short-term } \\
\text { market }(M C P)\end{array}$ \\
\hline \multicolumn{2}{|l|}{ Types of contracts involved: } & $\begin{array}{l}\text { How generators are } \\
\text { dispatched by ONS? }\end{array}$ & $\begin{array}{l}\text { How exposed positions } \\
\text { are settled by CCEE? }\end{array}$ \\
\hline $\begin{array}{l}\text { - CCEAR (Contract for } \\
\text { Electricity Trading in the } \\
\text { Regulated Environment) }\end{array}$ & $\begin{array}{l}\text { - CCEAL (Contract for } \\
\text { Electricity Trading in } \\
\text { the Free Environment) }\end{array}$ & \multirow{7}{*}{$\begin{array}{l}\text { - ISO knows the installed } \\
\text { capacity, availability, } \\
\text { and fuel cost of } \\
\text { generators. } \\
\text { - ISO also knows the } \\
\text { predicted consumption } \\
\text { due distribution } \\
\text { companies' monthly } \\
\text { declarations. } \\
\text { - ISO forecasts the } \\
\text { weather to stipulate } \\
\text { rivers inflows. } \\
\text { - It is run software based } \\
\text { on stochastic dynamic } \\
\text { and linear programming } \\
\text { to establish the dispatch } \\
\text { schedule and the PLD. }\end{array}$} & \multirow{7}{*}{$\begin{array}{l}\text { - All closed contracts (in } \\
\text { both } A C R \text { and } A C L \text { ) have } \\
\text { to be recorded in CCEE. } \\
\text { - CCEE performs } \\
\text { measurements of the } \\
\text { amounts actually } \\
\text { produced / consumed by } \\
\text { each agent. } \\
\text { - } M R E \text { is applied for } \\
\text { participants of this } \\
\text { mechanism. } \\
\text { - Differences between } \\
\text { contracted energy and the } \\
\text { verified energy are } \\
\text { accounted. } \\
\text { - Exposed positions are } \\
\text { valued by } P L D \text {. }\end{array}$} \\
\hline \multicolumn{2}{|c|}{$\begin{array}{l}\text { - CER (Contract for Reserve Energy), signed between } \\
\text { CCEE and sellers agents }\end{array}$} & & \\
\hline \multicolumn{2}{|c|}{$\begin{array}{l}\text { - CONUER (Contract for Use Reserve Energy), signed } \\
\text { between CCEE and consumption agents }\end{array}$} & & \\
\hline $\begin{array}{l}\text { - Contracts for Distributed } \\
\text { Generation }\end{array}$ & \multirow{4}{*}{$\begin{array}{l}\text { - } C C E I \text { (Contract for } \\
\text { Purchase Encouraged } \\
\text { Electricity) }\end{array}$} & & \\
\hline - Contracts of Adjustments & & & \\
\hline $\begin{array}{l}\text { - Contracts of PROINFA } \\
\text { (Program of Incentives } \\
\text { for Alternative Electricity } \\
\text { Sources) } \\
\end{array}$ & & & \\
\hline $\begin{array}{l}\text { - Contracts of Itaipu } \\
\text { Hydropower Plant }\end{array}$ & & & \\
\hline
\end{tabular}




\section{Problems}

Notwithstanding, there are some problems that arise from this market design, which are discussed below.

\subsection{Problem 1: The conciliation between the commercial commitments of the market participants and the physical dispatch is not smooth}

In order to trade both energy and power, several markets have emerged with the market liberalization: day-ahead, intraday, balancing, forward, future and options markets. However, when all these markets are operating together it should have a concern related with the coordination conditions between them. For instance, it is possible that weak links exist between forward and short-term markets, as well as between the distinct markets for electricity and reserves.

(Wilson, 1999) addresses this concern bringing the idea of the "sequence of markets", which means that a rich sequence of forward markets (e.g. long-forward, day-ahead, hour-ahead, spot) approximates a single complete market. Thus, the "incompleteness of the market" can be addressed by repeated trading of a few simple contracts in order to allow contingent contracts to come close to a complete market. As a result, frequent trading opportunities enhance the completeness of the entire market.

In the Brazilian case, there is no balancing market, neither an intraday, day-ahead, options nor future markets. Instead of that, there is an annual "window" to monthly distribute the physical guarantee and the contracted energy (via the seasonalization process already described) and, once the centralized dispatch is carried out by the ISO (not considering the signed contracts), generators are not allowed to, in the medium and the short-term, decide their own generation in order to bear their contracts. As shown in Figure 3, this can significantly expose them to the risk of having to buy electricity in the $M C P$ at the high volatile $P L D$ in order to deliver the energy committed in their contracts.

Figure 3 - Traded energy in MCP: negative exposition

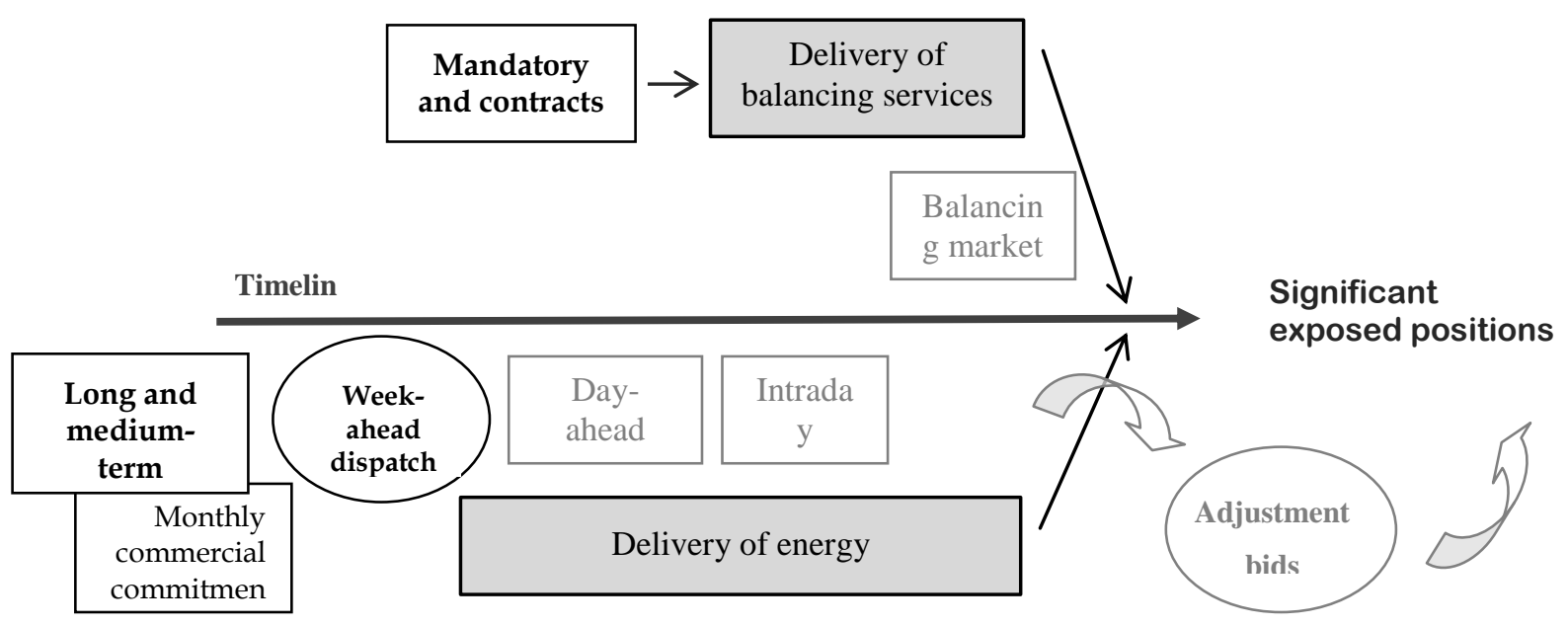

The issue regarding the conciliation between the commercial commitments of the market participants and the physical dispatch of the power system becomes more evident when the Brazilian electricity market is compared to other electricity markets around the world. Thus, to bring a broader outlook to this problem, Table 2 presents a helpful comparison.

On balance, in markets as day-ahead, intraday and balancing markets, players are more active in the definition of the merit order on a day-by-day basis and so they have more opportunities to cover 
their positions engaged by bilateral contracts. This fact can be viewed as a higher completeness of the market when compared with a market where participants close their positions by long-term contracts.

Table 2-Conciliation between physical dispatch and commercial commitments

\begin{tabular}{|c|c|c|c|c|}
\hline $\begin{array}{l}\text { Electricity } \\
\text { industry } \\
\text { structures }\end{array}$ & $\begin{array}{l}\text { Contracts between } \\
\text { market participants }\end{array}$ & System operator dispatch & $\begin{array}{l}\text { Conciliation between } \\
\text { dispatch schedule and } \\
\text { contracted positions }\end{array}$ & $\begin{array}{l}\text { Costs/prices passed on to } \\
\text { tariff of final consumers }\end{array}$ \\
\hline $\begin{array}{l}\text { Vertically } \\
\text { integrated } \\
\text { utility }\end{array}$ & $\begin{array}{l}\text { Without contracts } \\
\text { (command and control } \\
\text { management) }\end{array}$ & $\begin{array}{l}\text { System operator dispatches } \\
\text { considering the minimal } \\
\text { operational cost, since it a priori } \\
\text { knows each marginal cost. }\end{array}$ & $\begin{array}{l}\text { There aren't electricity } \\
\text { market and contracts } \\
\text { involved, so there isn't } \\
\text { need for conciliation. }\end{array}$ & $\begin{array}{l}\text { Consumers pay for the } \\
\text { cost of each MWh } \\
\text { produced based on cost } \\
\text { of service regulation. }\end{array}$ \\
\hline $\begin{array}{l}\text { Single buyer } \\
\text { model } \\
\text { (Brazilian } \\
\text { case) }\end{array}$ & $\begin{array}{l}\text { - Long-term contracts } \\
\text { (PPA) via public } \\
\text { auctions in the } A C R \\
\text { - Ancillary services are } \\
\text { provided by grid } \\
\text { codes and by } \\
\text { contracting for } \\
\text { reactive energy } \\
\text { - Medium-term } \\
\text { contracts in the } A C L\end{array}$ & $\begin{array}{l}\text { - Minimization of the operation } \\
\text { cost through the tight pool } \\
\text { approach. } \\
\text { ISO doesn't consider the amount } \\
\text { of electricity sold or bought } \\
\text { through contracts (it just uses the } \\
\text { price from the public auction to } \\
\text { perform the merit order). } \\
\text { Generators are not active in this } \\
\text { central-dispatch procedure. }\end{array}$ & $\begin{array}{l}\text { It is expected that } \\
\text { participants bear their } \\
\text { closed contracts by their } \\
\text { own production. However, } \\
\text { it is the ISO who decides } \\
\text { their outputs without } \\
\text { considering their contracted } \\
\text { amounts. So, it is needed a } \\
\text { mechanism (the MRE) to } \\
\text { share the associated risk. }\end{array}$ & $\begin{array}{l}\text { - Prices of the PPAs, } \\
\text { which have two } \\
\text { components: energy } \\
\text { payment and } \\
\text { availability payment; } \\
\text { PS: Participants settle } \\
\text { imbalances. }\end{array}$ \\
\hline $\begin{array}{l}\text { Wholesale } \\
\text { and retail } \\
\text { competition } \\
\text { (like Texas in } \\
\text { 2000) }\end{array}$ & $\begin{array}{l}\text { - Bilateral physical } \\
\text { contracts } \\
\text { - Balancing market } \\
\text { - Financial forward } \\
\text { contracts }\end{array}$ & $\begin{array}{l}\text { - Minimization of the difference } \\
\text { between the closed contract and } \\
\text { the real production. } \\
\text { In short-term, generators submit } \\
\text { notifications to the ISO/TSO, } \\
\text { which are expected to be equal to } \\
\text { contracted positions. ISO/TSO } \\
\text { dispatches considering these } \\
\text { notifications. Generators are } \\
\text { active through a self-dispatch } \\
\text { procedure. }\end{array}$ & $\begin{array}{l}\text { ISO/TSO tries to dispatch } \\
\text { the exact amount of the } \\
\text { physical notifications, i.e. } \\
\text { his goal is to minimize the } \\
\text { suppliers } \\
\text { position. }\end{array}$ & $\begin{array}{l}\text { - Prices coming from the } \\
\text { bilateral contracts and } \\
\text { balancing market; } \\
\text { PS: Participants settle } \\
\text { financial contracts and } \\
\text { imbalances. }\end{array}$ \\
\hline $\begin{array}{l}\text { Wholesale } \\
\text { and retail } \\
\text { competition } \\
\text { (like some } \\
\text { USA states, } \\
\text { and European } \\
\text { countries) }\end{array}$ & $\begin{array}{l}\text { - Short-term markets, } \\
\text { as day-ahead and } \\
\text { intraday } \\
\text { - Balancing market } \\
\text { - Financial and } \\
\text { physical forward } \\
\text { contracts }\end{array}$ & $\begin{array}{l}\text { - Minimization of the operation } \\
\text { cost through the loose pool } \\
\text { approach. } \\
\text { Sellers and buyers submit their } \\
\text { bids. Power Exchange dispatches } \\
\text { considering the successful bids. } \\
\text { Generators influence, through } \\
\text { their bids, the dispatch schedule. }\end{array}$ & $\begin{array}{l}\text { ISO/TSO implements } \\
\text { technical adjustments to } \\
\text { enforce } \\
\text { constraints. }\end{array}$ & $\begin{array}{l}\text { - Price of the short-term } \\
\text { markets and balancing } \\
\text { market; } \\
\text { PS: Participants settle } \\
\text { financial contracts and } \\
\text { imbalances. }\end{array}$ \\
\hline
\end{tabular}




\subsection{Problem 2: The Brazilian short-term market is a mechanism to settle differences rather than a market}

The $M C P$ takes place after the dispatch of the ISO. Unlike other market designs addressed in Table 2, the Brazilian short-term market is not the marketplace where generators are active through a selfdispatch procedure, or generators influence, through their bids, the dispatch. Ultimately, the Brazilian short-term market is not an environment where market participants meet in order to perform shortterm trades on behalf of their own account.

Neither party arrives at some point to make any declaration of intent in the short-term. Moreover, the price that values these transactions $(P L D)$ does not result from the interaction of market participants, but comes from the application of a chain of software packages, which is run by a third party entity. In summary, it would be a short-term market if, in this environment, market participants meet with each other in order to negotiate electricity and close agreements in the short-term according to their own will.

So, contrasting with other short-term markets, the $M C P$ is a mechanism to settle differences between the amounts of electricity committed by contracts and those amounts of electricity that each agent ends up providing / receiving. These differences, illustrated in the Figure 2, must be automatically purchased or sold in the $M C P$.

Figure 4 synthesizes relevant points related with this issue. Once all consumption has to be contracted ex-ante and contracts have to be physically backed, structurally the Brazilian market was designed to have no mismatches between the "computed long-term production (physical guarantee) and the foreseen consumption". As a consequence, it is the responsibility of the $M C P$ to deal with the differences that may occur due to the mismatch between the monthly verified energy and the contracted energy.

Figure 4 - An overview of the commercialization processes
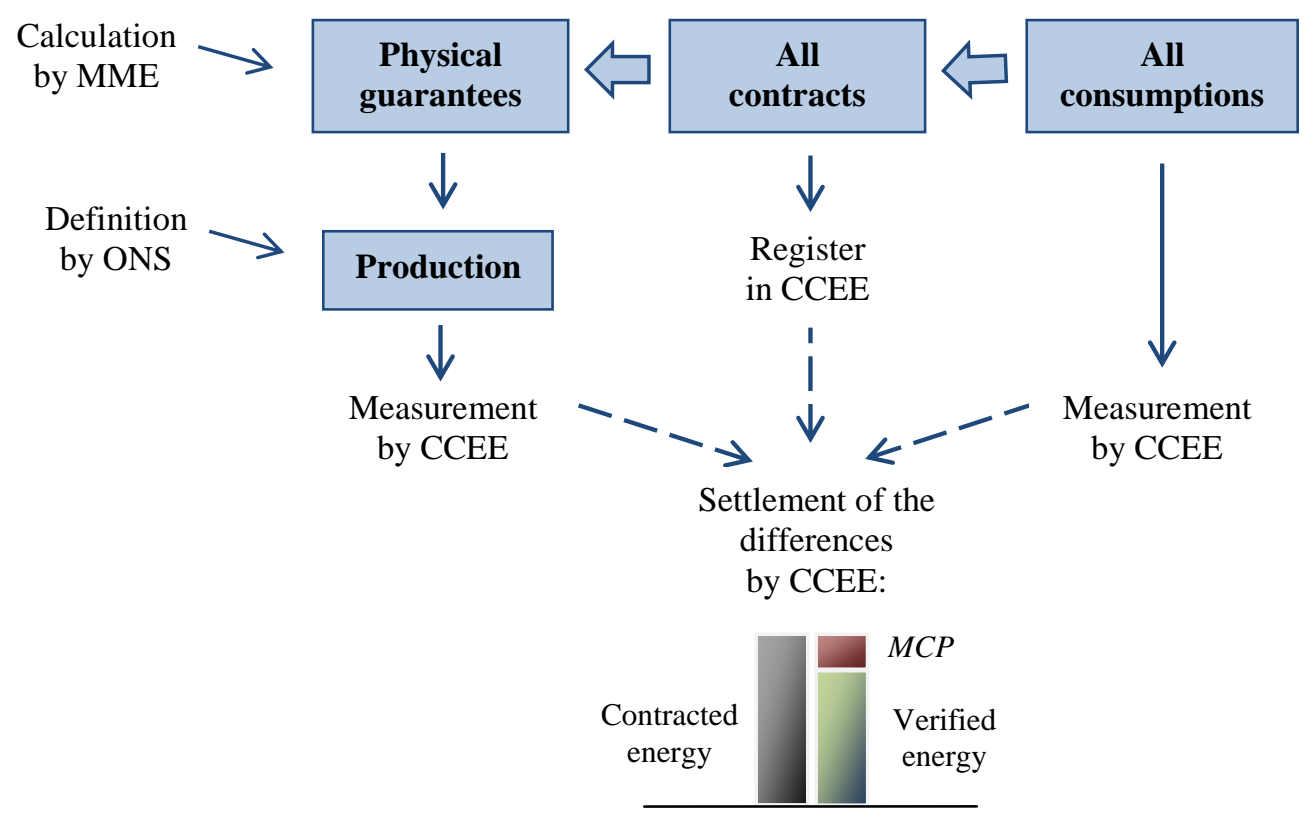

\subsection{Problem 3: The codes associated to the chain of software used to run the centralized dispatch are under intellectual property rights}

As previously indicated, it is not the market through the interaction between its participants that determines the electricity short-term market price and the dispatch schedule. Basically, since around 
$80 \%$ of the electricity produced in Brazil comes from hydropower plants, this is performed by two computational programs (NEWAVE and DECOMP) that value the present electricity cost considering, among other variables, future scenarios of water inflows.

Therefore, inconsistencies in these algorithms have a huge impact within the entire sector, and the confidence of the market can be affected. Unfortunately, during 2007 and 2011, relevant problems related with inconsistencies in these models were detected. These problems caused a large impact on the electricity sector, not to mention transparency problems since the software codes have intellectual property rights and, therefore, they are unknown by the market participants and the authorities, inducing some instability in the Brazilian electricity sector.

\section{Dilemmas}

A solution typically adopted in other markets is the employment of a more market oriented approach. This market approach could enable all generators to offer, in short-term, quantity and price bids, which would be used to set the market positions and, consequently, substitute the seasonalization process and the MRE. As a result, the short-term market price would be based on the interaction between market participants. Nevertheless, particularly focusing on a power system with large share of hydros, there are some dilemmas that must to be faced.

\subsection{Efficiency of energy resources}

The Brazilian and the New Zealand power systems are quite similar in terms of the importance of hydro generation. Both recently had around $60 \%$ of the electricity produced coming from hydropower plants (New Zealand System Operator, 2014) (ONS 2014a). However, in New Zealand generators make offers and are dispatched each half hour in a compulsory market pool. Thus, the offer stacks they submit are the only mechanism that they have to sculpt a varying generation plan to comply with their own constraints over the day.

Additionally, in New Zealand the vast majority of the hydros in the same river are operated by a single generation company, and there is a block dispatch scheme that allows generators to rearrange the dispatch amongst their stations on the river-chain, as long the total energy delivered is the same as the required stations are geographically close. Nonetheless, an empirical study performed by Philpott et. al., 2010 quantified some production efficiency losses of this market.

These authors developed a centrally-planned model in order to compare New Zealand market outcomes with a counterfactual central plan. The results show that the yearly centrally-planned policy incurs less fuel cost than the market approach. For 2005, 2006 and 2007, the saved fuel costs are, respectively, $16.0 \%, 13.4 \%$, and $14.6 \%$ of the total generation cost. In conclusion, the main source of the inefficiency pointed out by these authors relies on the fact that the New Zealand decentralized dispatch is essentially an instantaneous process and the inter-temporal features of river chain operations are not represented in the single-period market clearing mechanism.

Putting into perspective the dichotomy between a centralized dispatch (based on hierarchy) and a decentralized one (based on a market solution), it becomes clear the importance of the coordination of the use of the water stored in the reservoirs in order to safeguard the efficiency of using the energy resources. Moreover, the presence of several owners in the hydro cascades, which is the case of Brazil, endorses a market design based on a centralized dispatch.

\subsection{Security of supply}

Concerning the ability of the market to ensure sufficient capacity to meet the demand in the future, it must be kept in mind that generation companies will only invest in new power plants if they expect that their total costs (both variable and fixed costs) will be totally recovered in the end. Then, 
considering the hypotheses that Brazilian electricity market will be operated entirely based on a shortterm market, the following question arises: Will the response of generators regarding the short-term market prices come in the form of new installed capacity?

The Brazilian short-term market price, PLD is calculated for four submarkets (South, Southeast/Midwest, Northeast and North) and is set on a weekly basis for three load steps (heavy, medium and light). Regarding this issue, Figure 5 presents: the PLD curve ${ }^{l}$ (CCEE, 2014a); the hydro average successful price bid that came from public auctions (110.29 R $\$ / \mathrm{MWh}$ ) (CCEE, 2014b); the hydro Average Variable Cost - AVC (12.73 R $\$ / \mathrm{MWh})^{2}$; and the AVC starting point to dispatch the gas thermal power plants $(125 \mathrm{R} \$ / \mathrm{MWh})^{3}$ (ONS, 2014b). It is worth mentioning that the price bid in public auctions is the PPA contract price. Thus, the value 110.29 R $\$ / M W h$ can be perceived as the hydro Average Total Cost (ATC), once at this level it is expected to recover both the Variable Cost (VC) and the Fixed Cost (FC).

The Brazilian short-term market has about 15 years of existence. For the time being, the PLD has an average value of $109 \mathrm{R} \$ \mathrm{MWh}$. Therefore, it is close to the aforementioned 110.29. Nevertheless, it should be noted that, since the beginning of the PLD historical data, Brazil has passed through two large energy crises (in 2001-2002 and in 2013-2014) that made the PLD to remain in extreme levels for long periods. Besides, these so high price levels were not expected in a country that traditionally has an electricity matrix based on one of the lowest electricity production AVC technologies, hydro power.

Figure 5 - PLD historic data: from 2001 to 2014

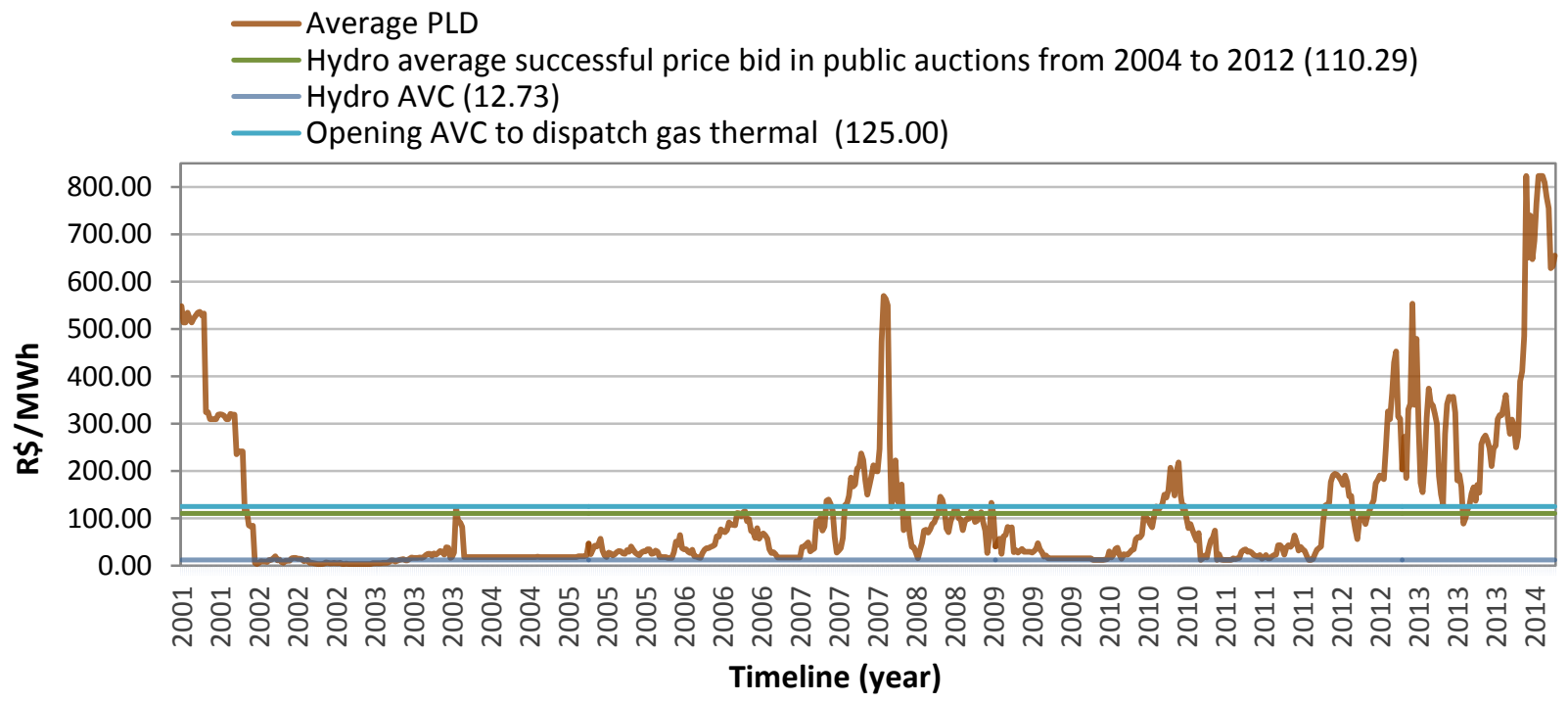

Anyway, supposing that from now on there will be more thermal stations in the dispatch and, thus, the $P L D$ will be frequently higher, the question is if the shape of the PLD curve will not be a barrier for the investment that intend to recover their FC and VC through the short-term market. At that point, the analysis rests on the $P L D$ volatility. The $P L D$ standard deviation of the entire set of data is around 160 $\mathrm{R} \$ / \mathrm{MWh}$. With an average of $109 \mathrm{R} \$ / \mathrm{MWh}$, a standard deviation equal to 160 imposes a big risk to the health of the business, especially regarding the stability of the cash flow.

$1 \quad P L D$ shown in this figure is merged considering the four submarkets and the three load steps.

$212.73 \mathrm{R} \$ \mathrm{MWh}$ was achieve by computing regarding hydros in Brazil with installed capacity higher than $100 \mathrm{MW}$ (ANEEL, 2012).

$3125 \mathrm{R} \$ / \mathrm{MWh}$ is equivalent to the percentile 20, i.e., $80 \%$ of the gas thermal power plants have a AVC higher than 125 $\mathrm{R} \$ \mathrm{MWh}$. 
Finally, it is recognized the need to have a capacity mechanism in order to provide enough incentives to ensure the security of supply. Nowadays, this concern is addressed both via the contracting scheme where loads must to be fully ex-ante contracted and contracts physically backed, and via the dispatch of the ISO (either through the mechanism of risk aversion implement into the NEWAVE and DECOMP or through a dispatch out of the merit order authorized by a the CMSE Electricity Sector Monitoring Committee ${ }^{4}$ ).

\subsection{Flexibility to bear contracts}

Notwithstanding the general opinions favor maintaining the current centralized dispatch in order to ensure the efficiency in the use of the energy resources and the security of supply, it is missing in the electricity market design some flexibility for hydros to better address their risk of exposition in the short-term market according to their own risk perception and strategy.

There is one unique "window" (in December) to define the (monthly) amount of the physical guarantee that will bear the contracts. Taking into account the market completeness analysis, there is a lack of "trading opportunities". Moreover, generators operate their power plants just following the amount of production defined by the ISO, and the MRE is automatically performed, which imposes a kind of strait jacket to the market participants. Taking a closer look at the seasonalization process and at $M R E$, the following situation brings to light a weakness of this market design.

Every time that $P L D$ is high, there are more dispatched thermal stations and less hydro dispatched units. Thermal power plants are typically contracted in the "modality for availability", so they receive an availability payment and an additional remuneration for each MWh produced. Nevertheless, hydros are normally contracted in the "modality for quantity", i.e. they are committed to deliver a certain amount of electricity (MWh) at a pre-defined price, and the difference between the contracted energy and the verified energy must be automatically bought or sold in the $M C P$ at the PLD.

Depending on the amount of thermal dispatch, hydros can be displaced in such a way that the total production in the MRE will not be larger or equal than the total physical guarantee of the MRE's hydros. As a result, $M R E$ will not have the extra energy to be shared among its participants. Unlike, an adjustment factor will be applied to withdraw a fraction from the seasonalized physical guarantee. Extending this reasoning to occasions of water scarcity, a large decrease in the seasonalized physical guarantee of all hydros participants of the MRE (current there are 528 hydros in the $M R E$ ) represents a widespread negative exposed position for these hydros.

In order to illustrate this situation, Table 3 presents the allocation procedure considering four power stations having a total of generation of $80,000 \mathrm{MWh}$. The total verified energy to be allocated to each hydro is given by the multiplying of their own production by the adjustment factor (eq. 1). The adjustment factor is computed as the ratio between the total production and total seasonalized physical guarantee into the $M R E$ (eq. 2).

Verifed energy $=($ adjustment factor $) \times($ Own production $)$

Adjustment factor $=($ total MRE production $) \div($ total MRE physical guarantee $)$

\footnotetext{
4 The CMSE is an authority established to mainly assess the conditions of supply adequacy of the country.
} 
Table 3 - Into MRE: when things go really bad

\begin{tabular}{|c|c|c|c|c|c|c|c|c|}
\hline Hydro & $\begin{array}{c}\text { Own } \\
\text { production } \\
\text { (MWh } x \\
1,000)\end{array}$ & $\begin{array}{c}\text { Physical } \\
\text { guarantee } \\
(\mathrm{MWh} x \\
1,000)\end{array}$ & $\begin{array}{l}\text { Adjustment } \\
\text { factor }\end{array}$ & $\begin{array}{c}\text { Verified } \\
\text { energy } \\
(\mathrm{MWh} x \\
1,000)\end{array}$ & $\begin{array}{c}\text { TEO } \\
\text { (R\$/MWh) }\end{array}$ & $\underset{(\mathrm{R} \$ / \mathrm{MWh})}{\text { PLD }}$ & $\begin{array}{c}\text { Contracte } \\
\text { d energy } \\
(\mathrm{MWh} x \\
1,000) \\
\end{array}$ & $\begin{array}{c}\text { Financial } \\
\text { Settlement } \\
(\mathrm{R} \$)\end{array}$ \\
\hline Hydro A & 37 & 50 & \multirow{4}{*}{0.571} & 28.57 & \multirow{4}{*}{10.54} & \multirow{4}{*}{700.00} & 50 & $-14,911,163$ \\
\hline Hydro B & 12 & 40 & & 22.86 & & & 40 & $-12,114,434$ \\
\hline Hydro C & 7 & 20 & & 11.43 & & & 20 & $-6,046,677$ \\
\hline Hydro D & 24 & 30 & & 17.14 & & & 30 & $-8,927,726$ \\
\hline Total $=$ & 80 & 140 & - & 80.00 & - & - & 140 & $-42,000,000$ \\
\hline
\end{tabular}

Since the total production $(80,000 \mathrm{MWh})$ is less than the total allocated physical guarantee $(140,000$ $\mathrm{MWh}$ ), the adjustment factor (0.571) will be lower than one, and the verified energy will not fill the level of the physical guarantee. Considering the TEO (Energy Optimization Tariff) ${ }^{5}$ established for 2014 (10.54 R \$/MWh) (Approving Resolution ANEEL 1658/2013) and a PLD consistent with a situation of energy shortage (700 R $\$ / \mathrm{MWh}$ ), the total financial settlement associated to the operation for these hydro stations is equal to a loss of R \$ 42 million (or about U\$ 18 million).Accordingly, all hydros stations must make substantial payments. Admitting that this situation will last for some months and that a plenty of hydro stations have to buy energy in the $M C P$ at a very high $P L D$, this can seriously affect their cash flow.

In short, in situations like the one illustrated above, the $M R E$ is not able to cover the risk of generators that have to buy electricity in the short-term market to complete the energy committed in their contracts. This risk is called "hydrological risk" once hydros are being dispatched at lower levels because there is no enough water in their reservoirs. Unluckily, nowadays Brazil is facing a situation like this. Due to an unusual rainfall cycle that has lasted since 2012, the power system has a widespread water shortage, a large thermal dispatch and sky-rocketing short-term market prices. For this reason, hydros appealed to the Federal Government for financial support as reported in a Brazilian newspaper:

"Hydro generators prepared a request for help to the Federal Government in order to equalize the negative financial impact on the revenues of hydro power plants participating in the Mechanism for Reallocation of Energy (MRE). Consultants estimate that the exposure of the generators to the short-term market can cause a loss of over R $\$ 20$ billion in 2014." (Jornal da Energia, 2014b)

The Federal Government has been arguing that this is a business risk of hydros, and that it does not intend to relieve them. Hydros argue that the growing PLD curve was not taken into account by generators at the moment that they signed the long-term contracts. At the long term, this arm wrestling suggests that there will be a point in which the economic and financial balance of the projects can be severely affected. Pragmatically speaking, within this conjuncture the question to be answered is as follows: for how long this negative exposition can be supported by hydro companies?

If each hydro would decide its own production, the management of their reservoir would be on their own. However, in the Brazilian case, the decisions regarding each production level, and consequently the amount of energy to be stored in the reservoirs, is made by a third party, the ISO. Nonetheless, hydrological risk is assumed by hydros, once the MRE doesn't covers this risk. As pointed out by (IEA, 2005), the framework of incentives should be structured such that risks are allocated to those who make decisions and who hold responsibility for taking them into account. Lastly, this unsuitability emphasizes that it is missing in the market design some flexibility so that hydro companies can manage this risk in a more adequate way.

5 The $T E O$, expressed in $\mathrm{R} \$ \mathrm{MWh}$, is established by ANEEL and aims to financially compensate hydros that provide energy to the MRE. 


\section{A New Market Design}

Focusing on the enhancement of the flexibility for market participants to bear their contracts, while still ensuring the efficiently use of the energy resources and maintaining the current level of the security of supply, and bearing in mind some proposals of interventions in the Brazilian electricity market (Revitalization Committee of the Electricity Sector, 2002) (Simba, 2005), a new market design was developed to be applied to hydrothermal systems. This market design is supported by the following proposed virtual reservoir model:

- Each cascade of hydro stations operates as an equivalent reservoir;

- Each agent has a virtual account that represents how much energy is virtually stored in his hydropower plant;

- For each accounting period, each account is fed by the fraction of the total affluent energy of the equivalent reservoir proportional to the hydro's physical guarantee.

Then, the ensuing sequence of events should be followed:

$\mathbf{1}^{\mathbf{0}}$ The system operator does his work as it currently does (running NEWAVE, DECOMP as well as other software, procedures and schemes), and defines the amount of generation for each power plant. So, the efficiency of the use of the energy resources and the security of supply are maintained at the current levels;

$\mathbf{2}^{\mathbf{0}}$ It is calculated the "remaining demand", which is equal to the total demand minus the total dispatch of the thermal power plants;

$3^{\mathbf{0}}$ It is established a liberalized hydro short-term market for this remaining demand:

a. Regarding the price bid: hydros can bid a price between zero and the cost of the cheaper thermal power plant dispatched in this period;

b. Regarding the quantity bid: each agent can offer any value within the balance of his account;

$4^{\mathbf{0}}$ The final short-term market price is calculated as a weighted average considering the hydro short-term market price that comes from the hydro virtual short-term market and the variable cost of the dispatched thermal power plants and other energy sources.

Thus, as can be observed in Figure 6, two worlds would coexist: the real one, associated with the power system considering physical effects; and the virtual one, related with the settlement system and with commercial effects.

\section{Figure 6 - Physical system (ISO operation) versus Commercial system (agents operation)}
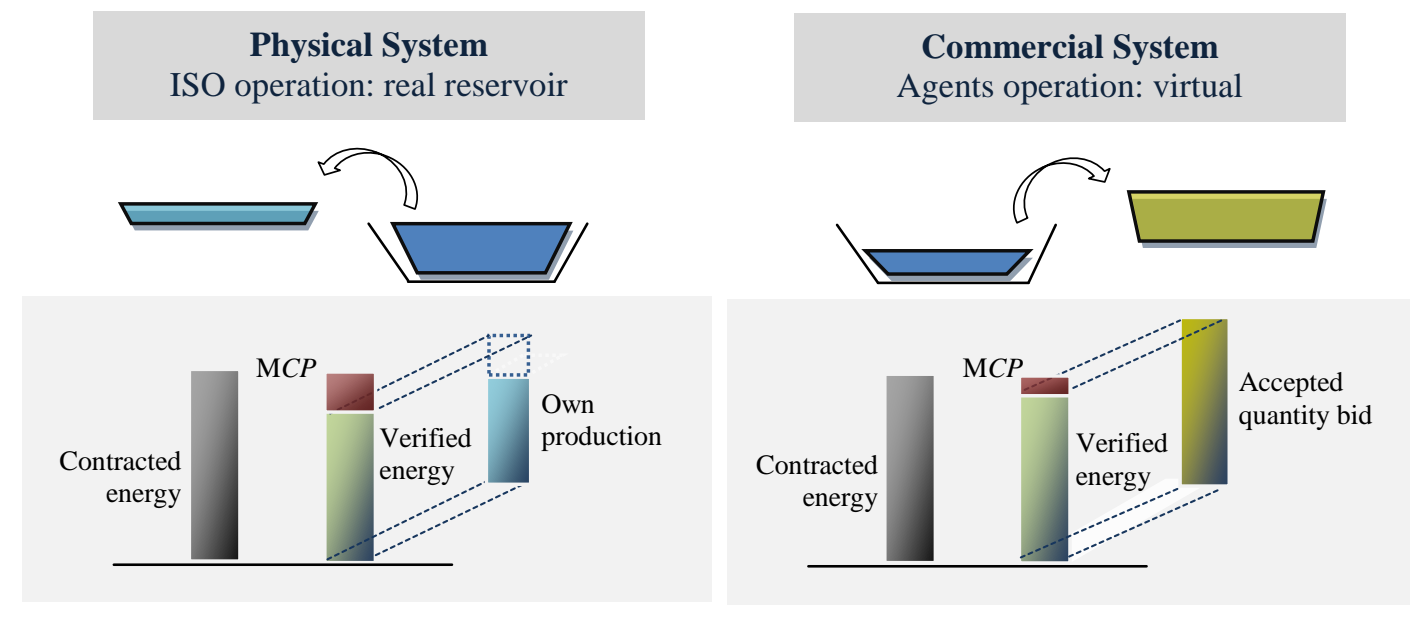
Through this market design, agents would be responsible for deciding, in commercial terms, how much they want to withdraw from their virtual reservoirs to meet their contracts. To do that, their bids have to be accepted in an auction that will be performed as a day-ahead market. In doing so, each generator has the opportunity to manage his contracts more efficiently, without affecting the real operation of the physical system.

Furthermore, this model promotes a monitoring of the ISO performance based on comparisons between his decisions (the physical world) and the market participants decisions (virtual world). To address this issue, Figures 7 presents a scheme illustrating the decision making process in this new market design.

\section{Figure 7 - Decision making process: ISO decides to use water; agent decides to save water}

Time t0: Both systems (physical and commercial) start equal
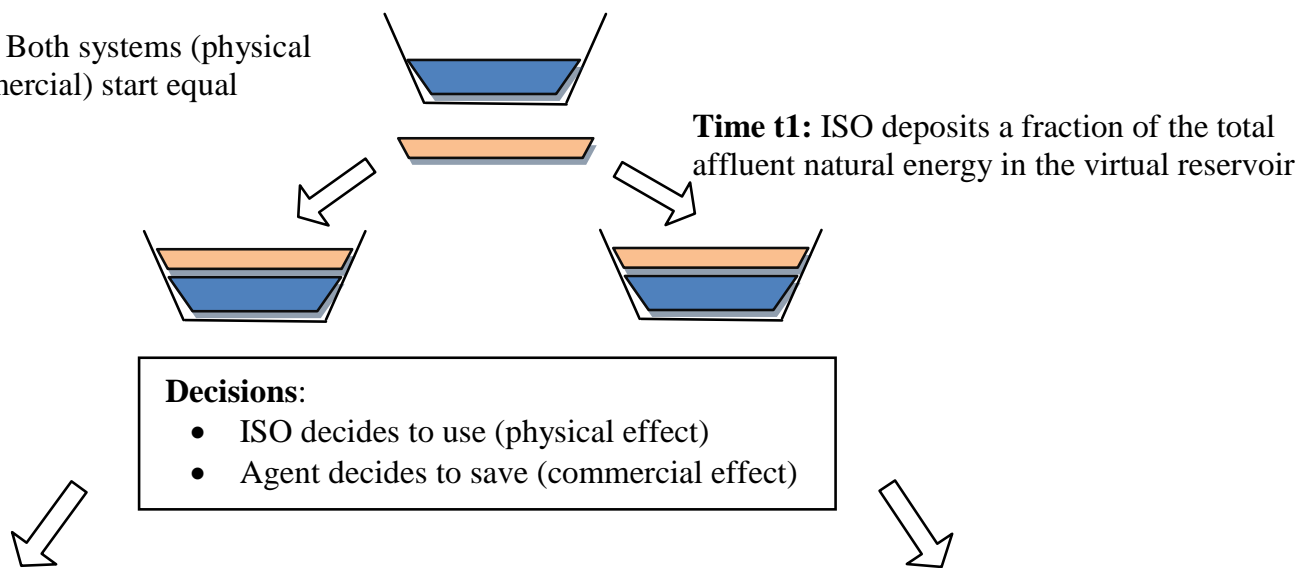

What did occur in the period?

Answer: High water inflows!

- So, ISO took the best decision

What did occur in the period?

Answer: Low water inflows!

- So, Agent took the best decision

ISO Operation Real Reservoir

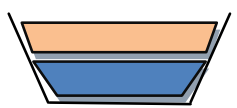

Gain for the ISO:

- Positive image.
Agent Operation Virtual Reservoir

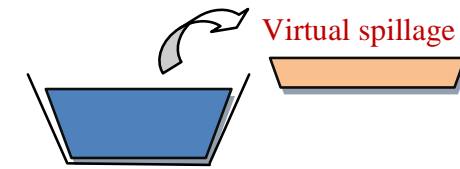

Loss for the Agent:

- Agent lost the opportunity to sell this energy spillage.
ISO Operation Real Reservoir

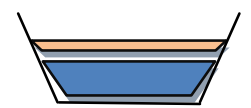

Loss for the ISO:

- Negative image since the ISO performance lower than Agent.
Agent Operation Virtual Reservoir

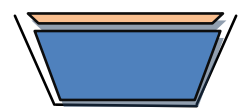

Gain for the Agent:

- In scenario of water scarcity, energy is more expensive. And agent has large amount of energy to offer.

In Figure 7 the ISO decided to use water, while the generation agent decided to save it. When these decisions are reversed (ISO decided to save and the agent to use), instead of having a virtual spillage, as shown in Figure 8, it can happen a physical spillage. 


\section{Figure 8 - Decision making process: ISO decides to save water; agent decides to use water}

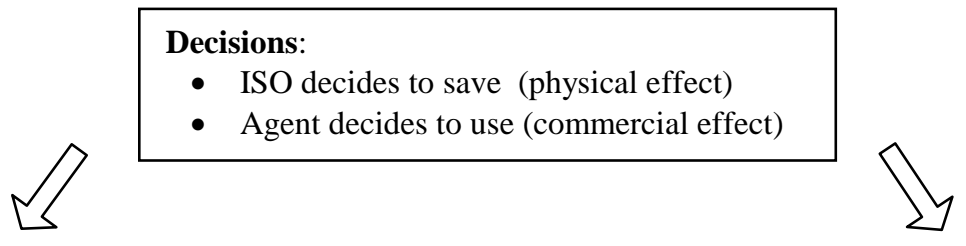

What did occur in the period? Answer: High water inflows!

- So, Agent took the best decision

ISO Operation Real Reservoir

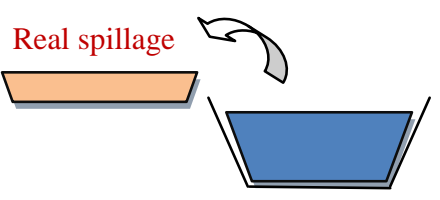

Loss for the ISO:

- Negative image since the ISO had a performance lower than the market.
Agent Operation Virtual Reservoir

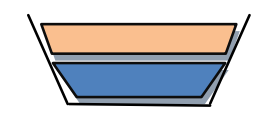

Gain for the Agent:

- Agent has the opportunity to sell this energy.

What did occur in the period? Answer: Low water inflows!

- So, ISO took the best decision

ISO Operation Real Reservoir

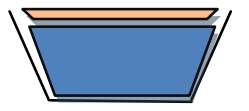

Gain for the ISO:

- Positive image.
Agent Operation Virtual Reservoir

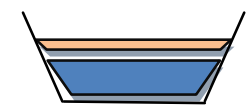

Loss for the Agent:

- In scenario of water scarcity, energy is more expensive. However, agent has small amount of energy to offer.

At the end of this process, the prices no longer result primarily from a chain of computational models that may eventually present problems related with inconsistencies and transparency, but they can be obtained through the combination of thermal costs originated from the ISO dispatch and the short-term market price arising from the liberalized hydro short-term market.

Thereby, this market design maintains the same levels of the previously mentioned efficiency and security, while increases the level of flexibility of the agents' commercial aspects. This flexibility can be achieved by replacing the MRE and the seasonalization process by a virtual reservoir model. As a result, the management of (virtual) reservoirs is the responsibility of each hydro, which could save (virtual) water according to their own risk perceptions and in doing so the operation of the physical system is not affected at all. 


\section{References}

ANEEL - Brazilian Electricity Regulatory Agency. Thematic Notebook 3: Assured Energy. Available at: http://www.aneel.gov.br/arquivos/pdf/caderno3capa.pdf Accessed: May 12, 2013.

ANEEL - Brazilian Electricity Regulatory Agency. Administrative Process number: 48500.005619/2012-48. Opened in 2012.

Approving Resolution ANEEL 1667/2013, which approves the values of the Deficit Cost Curve and the minimum and maximum limits of the PLD for the year 2014. December 10, 2014.

Arango, S.; Dyner, I.; Larsen, E. R. Lessons from deregulation: Understanding electricity markets in South America. Utilities Policy 14 (2006) 196-207.

CCEE - Electric Power Commercialization Chamber. Procedures of Commercialization. Módule 3: Contracting of energy and Power. Sub-module 3.3: Seasonalization and review of seasonalization of physical guarantee. Revision 1.0, Effective Date: December 11, 2012.

CCEE - Electric Power Commercialization Chamber. Prices. Available at: http://www.ccee.org.br /portal/faces/pages_publico/o-que-fazemos/como_ccee_atua/precos/precos_csv?_afrLoop= 2376344541042153\#\%40\%3F_afrLoop\%3D2376344541042153\%26_adf.ctrl-state\%3D150 pkd91cy_75 Accessed: May 21, 2014a.

CCEE - Electric Power Commercialization Chamber. Info Auction $n^{\circ}$ 001: 15 $5^{\circ}$ New Energy Auction. Available at: http://www.ccee.org.br/portal/wcm/idc/groups/bibpublic_precos/documents/ conteudoccee/ccee_072146.pdf Accessed: May 21, 2014b.

Revitalization Committee of the Electricity Sector. GT2 - Implementation of the price offer system in the electricity market. Final Report. Brasilia: Ministry of Mines and Energy, 2002.

Decree 5163/2004, which regulates the trade of electricity, the process of concessions and authorization of the electricity generation, among other measures. July 30, 2004.

IEA - International Energy Agency. Energy market experience: Lessons from liberalized electricity markets. Paris: OECD/IEA, 2005.

Jornal da Energia. Generators tailor request for help to the government: The goal is to seek a solution to the financial impact caused by water deficit. Available at: http://www.jornalda energia.com.br/mobile/ler_noticia.php?n=16988 Accessed: June 12, 2014b.

Law 10848/2004, which provides rules regarding the commercialization of electricity. March 15, 2004.

Maurer, L.; Pereira, M.; Rosenblatt, J. Implementing Power Rationing in a Sensible Way: Lessons Learned and International Best Practices. Energy Sector Management Assistance Program. Report 305/05. August, 2005.

New Zealand System Operator. Generation Mix. Available at: http://www.systemoperator. co.nz/security-supply/sos-weekly-reporting/generation-mix Accessed: May 14, 2014.

ONS - Brazilian Electric System Operator. Informative Preliminary agenda of Operation - IPDO. Available at: http://www.ons.org.br/resultados_operacao/ipdo.aspx Accessed: May 14, 2014a.

ONS - Brazilian Electric System Operator. ONS NT-0080-207-2014. Monthly program of energy operation for the month of May 2014: Executive Summary. Available at: http://www.ons. org.br/operacao/NTsumarioexecutivoPMO.aspx Accessed: May 20, 2014b.

Philpott, A.; Guan, Z.; Khazaei, J.; Zakeri, G. Production inefficiency of electricity markets with hydro generation. Utilities Policy 18, 2010, pages 174-185. 
Rosa, L. P.; Silva, N. F.; Pereira, M. G.; Losekann, L. D. Chapter 15 - The Evolution of Brazilian Electricity Market. In: Evolution of Global Electricity Markets: New Paradigms, New Challenges, New Approaches. Fereidoon P. Sioshansi, Academic Press: Boston, 2013. Pages 435-459.

Simba, J. C. C. Energy dispatch and price formation through auctions in hydro predominant system. Thesis presented to COPPE/UFRJ. May, 2005.

Wilson, R. Market Architecture. Stanford Univesity, 1999. Available at: http://www2.econ. iastate.edu/tesfatsi/MarketArchitecture.RWilson1999.pdf Accessed: February 5, 2014. 


\section{Author contacts:}

\section{Felipe Alves Calabria}

Brazilian Electricity Regulatory Agency

MIT Portugal Program, Faculty of Engineering, University of Porto

Florence School of Regulation, European University Institute

Email: felipecalabria@aneel.gov.br

\section{J. Tomé Saraiva}

Professor at the Department of Electrical and Computer Engineering, Faculty of Engineering, University of Porto

Email: jsaraiva@fe.up.pt

\section{Jean-Michel Glachant}

Director of the Florence School of Regulation and holder of the "Loyola de Palacio" Chair RSCAS, European University Institute

Email: jean-michel.glachant@eui.eu 